\title{
Applications of Biochar and Modified Biochar in Heavy Metal Contaminated Soil: A Descriptive Review
}

\author{
Meina Liang ${ }^{1,2,3}$, Lin Lu ${ }^{1}$, Huijun He ${ }^{1,2,3, *}$, Jingxi Li ${ }^{1}$, Zongqiang Zhu ${ }^{1,2,3,4}$ (D) and Yinian Zhu ${ }^{1,2,3}$ \\ 1 College of Environmental Science and Engineering, Guilin University of Technology, Guilin 541004, China; \\ liangmeinaa@163.com (M.L.); lulululululin@163.com (L.L.); ljx3402309930@163.com (J.L.); \\ zhuzongqiang@glut.edu.cn (Z.Z.); zhuyinian@163.com (Y.Z.) \\ 2 Guangxi Key Laboratory of Environmental Pollution Control Theory and Technology, \\ Guilin University of Technology, Guilin 541004, China \\ 3 Guangxi Collaborative Innovation Center for Water Pollution Control and Water Safety in Karst Area, \\ Guilin University of Technology, Guilin 541004, China \\ 4 Technical Innovation Center of Mine Geological Environmental Restoration Engineering in Southern Karst \\ Area, Nanning 530022, China \\ * Correspondence: hehuijun@hnu.edu.cn
}

Citation: Liang, M.; Lu, L.; He, H.; Li, J.; Zhu, Z.; Zhu, Y. Applications of Biochar and Modified Biochar in Heavy Metal Contaminated Soil: A Descriptive Review. Sustainability 2021, 13, 14041. https://doi.org/ $10.3390 /$ su132414041

Academic Editor: Salvatore Cataldo

Received: 14 November 2021 Accepted: 16 December 2021 Published: 20 December 2021

Publisher's Note: MDPI stays neutral with regard to jurisdictional claims in published maps and institutional affiliations.

Copyright: (c) 2021 by the authors. Licensee MDPI, Basel, Switzerland. This article is an open access article distributed under the terms and conditions of the Creative Commons Attribution (CC BY) license (https:// creativecommons.org/licenses/by/ $4.0 /)$.

\begin{abstract}
Given that the problem of contaminated soil continues to grow, the development of effective control and remediation measures has become imperative, especially for heavy-metal-contaminated soil. Biochar and modified biochar are eco-friendly and cost-effective remediation materials that are widely used in the remediation of contaminated soil. This review provides an overview of the different raw materials used in the preparation of biochar as well as the modification of biochar using various synthesis methods, highlighting their differences and providing recommendations for biochar and modified biochar as applied toward ameliorating pollution in soil contaminated by heavy metals. We also explore the effects of the physicochemical properties of raw materials, pyrolysis temperature, additives, and modification methods on the properties of the resulting biochar and modified biochar, and systematically present the types of soil and operating factors for repair. Moreover, the mechanisms involved in remediation of heavy-metal-contaminated soil by biochar and modified biochar are outlined in detail, and include adsorption, complexation, precipitation, ion exchange, and electrostatic attractions. Finally, the corresponding monitoring technologies after remediation are illustrated. Future directions for studies on biochar and modified biochar in the remediation of contaminated soil are also proposed to support the development of green environmental protection materials, simple preparation methods, and effective follow-up monitoring techniques.
\end{abstract}

Keywords: biochar; modified biochar; heavy metal; remediation mechanism; soil

\section{Introduction}

Soil provides a medium for plant growth as well as a habitat for insects and organisms. In recent years, economic progress has rapidly accelerated the ongoing expansion of manufacturing. Concurrently, large amounts of wastewater [1], and waste residue [2] from ore extraction, smelting, chemical fertilizer applications, and chemical production are being discharged into the soil [3]. Among the numerous pollutants, the contamination of soil with heavy metals such as $\mathrm{Hg}, \mathrm{Pb}, \mathrm{Cd}, \mathrm{Cu}$, and As has become a widespread concern [4-7] because such metals are highly toxic, degradation-resistant, and easily accumulate in the environment [8]. They will also cause great harm to human health after entering human body through soil-plant-animal-human biological chain [9]. Therefore, techniques to reduce the accumulation and bioavailability of heavy metals in contaminated soil are urgently needed.

At present, the remediation methods of heavy-metal-contaminated soil are mainly divided into physicochemical remediation [10,11], chemical remediation [12], phytoreme- 
diation [13], and bioremediation [14]. Physicochemical remediation involves changing the $\mathrm{pH}$, redox conditions, or ion composition of soil by adding amendments to achieve the purpose of passivating heavy metals in the soil [15]. Phytoremediation is mainly achieved through improving the tolerance of plants to heavy metals as well as their ability to remove them, or reduce the accumulation of heavy metals in plants [16]. Bioremediation involves using some microorganisms in the soil to absorb and precipitate heavy metals or reducing the toxicity of heavy metals via the redox action of microorganisms [17]. Electric remediation is a new economical technology in soil remediation that offers a very strong removal effect for heavy-metal ions such as $\mathrm{Cr}^{3+}$ in sandy soil [18]. In these remediation methods, biochar remediation is widely used because of its low price, easy availability, and remarkable remediation effects on heavy-metal ions [19].

Biochar possesses a large surface area and the property of strong remediation of heavy metals and is widely employed for soil remediation [20]. The sources of biochar include wood [21], agricultural and forestry waste [22], industrial waste [23], and emerging algae organisms are a type of renewable resource. Using biochar as a soil-remediation material not only reduces the cost of soil remediation but also reduces resource wastages. In addition, the physicochemical properties of biochar, such as porous structure, and hydroxyl and carbonyl groups, could contribute to degradation of heavy-metal pollutants [24]. As a superior-quality and low-cost environmental amendment, it has been indicated that biochar could serve as an alternative material for amending soils contaminated with heavy metals [25]. Meanwhile, to further improve the remediation performance of biochar and resolve difficulties in subsequent separation of the soil and the applied biochar, researchers have sought various methods to modify biochar. Table 1 shows the advantages and predicaments of biochar and modified biochar in the remediation of contaminated soil.

Table 1. Current status of biochar and modified biochar research.

\begin{tabular}{cc}
\hline Advantages of Application of Biochar and Modified Biochar & Current Problems \\
\hline $\begin{array}{c}\text { The combination of biochar and modified biochar with fertilizer } \\
\text { can promote the growth and the yield of crops. }\end{array}$ & $\begin{array}{c}\text { Application of large amounts of biochar and modified biochar } \\
\text { can cause soil nutrient imbalance. }\end{array}$ \\
\hline $\begin{array}{c}\text { They can reduce the mineralization rate of soil organic matter, } \\
\text { inhibit the activity of methanogens, and alleviate the } \\
\text { greenhouse effect [26]. }\end{array}$ & $\begin{array}{c}\text { A small amount of polycyclic aromatic hydrocarbons (PAHs) } \\
\text { remains in biochar after pyrolysis, which affects its usage [27]. }\end{array}$ \\
\hline $\begin{array}{c}\text { After application, the organic matter content, CEC, and EC of } \\
\text { the soil increase. }\end{array}$ & $\begin{array}{c}\text { It has negative effects on the activity of some soil microbial } \\
\text { communities [28]. }\end{array}$ \\
\hline $\begin{array}{c}\text { They can increase the basal respiration and biomass of soil } \\
\text { microorganisms [29]. }\end{array}$ & $\begin{array}{c}\text { The effect of some biochars in the remediation of contaminated } \\
\text { soil is poor. } \\
\text { They can absorb water, and increase water retention of soil [30]. }\end{array}$ \\
\hline
\end{tabular}

In recent years, the experimental studies about the application of biochars and modified biochars in the remediation of heavy metals contaminated soil have been reported extensively, however, there are few review articles on the application of biochars and modified biochars in the remediation of heavy-metal-contaminated soil. Therefore, we review the studies of these two kinds of biochars in heavy-metal-contaminated soil to make readers understand the existing research results and the latest progress in this field. More specifically, we wish to examine the following factors: (1) the types and sources of raw materials for preparing biochar and modified biochar; (2) the preparation methods for biochar and modified biochar; (3) the application of biochar and modified biochar in remediation of heavy-metal-contaminated soil, including remediation techniques, influencing factors, remediation mechanisms, and follow-up environmental monitoring; and (4) future prospects of biochar and modified biochar in the remediation of contaminated soil. 


\section{Preparation of Biochar and Modified Biochar}

\subsection{Raw Materials}

\subsubsection{Wood}

Recently, many studies have shown that raw wood and waste wood are the most important and common materials used for the preparation of biochar because trees are resilient and can grow well even under harsh environments, thereby representing an abundant source of material. At present, raw materials for biochar mainly include eucalyptus [31] and mulberry [32]; the biochars prepared from these materials were shown to be good adsorbents for removing toxic substances in contaminated soil [33]. For example, the rates of copper and lead removal from the soil were $93 \%$ and $90 \%$ when using biochars prepared with eucalyptus and pine, respectively [34,35]. At the same time, wood-prepared biochar is often used as a carrier to prepare modified biochar.

\subsubsection{Agricultural and Forestry Waste}

The use of agricultural and forestry waste to prepare biochar is an effective approach for biomass resource utilization [36]. Being low in cost and easy to obtain, this kind of biochar has attracted attention in the field of pollution control [19]. Biochar prepared from such agricultural wastes as seed shell [3], corn cob [37], corn straw [38], and potassium-iron rice straw could effectively remove $\mathrm{Cu}^{2+}$ and $\mathrm{Pb}^{2+}$ ions in soil; the removal capacities for $\mathrm{Cu}^{2+}, \mathrm{Pb}^{2+}$, and $\mathrm{Cd}^{2+}$ reached $1.67,2.08$, and $0.41 \mathrm{mmol} / \mathrm{kg}$, respectively. Raw materials also include livestock manure and animal bones [39,40].

\subsubsection{Industrial Waste}

Industrial waste mainly includes organic wastes produced in industry and daily life such as sludge [21] and municipal solid waste [41]. Research on the preparation of biochar from industrial waste increased by 70\% from 2010 to 2019. In the study of Wang et al. [42], when the pyrolysis temperature was $750{ }^{\circ} \mathrm{C}$, the biochar prepared from industrial waste cork was shown to be an effective adsorbent for $\mathrm{Cu}^{2+}$ removal, and the maximum adsorption capacity was $18.5 \mathrm{mg} / \mathrm{g}$.

\subsubsection{Algae Organism}

Researchers have recently been interested in biochar derived from algal biomass. This kind of biochar offers strong ion exchange and can also be utilized as an agricultural soil conditioner [1,43]. Biochar prepared from algae organisms can be an effective agent in the remediation of contaminated soil. In some studies, the $\mathrm{N}$ content of biochar extracted from microalgae exceeded $4 \%$, meaning that such biochar can be used as fertilizer for agricultural soil [44].

Currently, raw materials are relatively simple. For example, the most commonly used raw materials are wood and straw. With the expansion of urbanization, a large number of municipal organic wastes, such as municipal sludge and garden waste, enter the environment. In order to repair the contaminated soil and reduce its related risks [45], they may be the main raw materials used to prepare biochar in the future, which can combine the improvement of farmland-urban environment.

\subsection{Preparation Methods for Biochar and Modified Biochar}

\subsubsection{Biochar}

Biochar is a solid material produced by the thermochemical conversion of biomass under oxygen-limited conditions [46] and offers the properties of higher chemical stability, thermal stability, and biological inertness [47]. Biochar is produced via the pyrolysis (or gasification, hydrothermal carbonization, or flash carbonization) of biomass materials under high-temperature and anoxic conditions [48]. The preparation methods for biochar are classified as follows.

(1) Direct pyrolysis at a high temperature under nitrogen or carbon dioxide conditions is the most common method for biochar preparation. Figure 1 shows a schematic 
diagram of biochar production by pyrolysis. In this method, the dried biomass feedstock is first put into a muffle furnace. The air in the furnace is then pumped out with a vacuum pump to form pyrolysis conditions, the furnace is heated to a certain temperature at a certain rate, and nitrogen is then injected into the furnace [49]. Through this method, raw materials (apple pomace, kelp, cow dung, biofilm, etc.) can be used to prepare biochar $[11,31,32]$. Pre-carbonized biochar can be further activated to obtain high-performance biochar by adding activators such as potassium hydroxide [50].

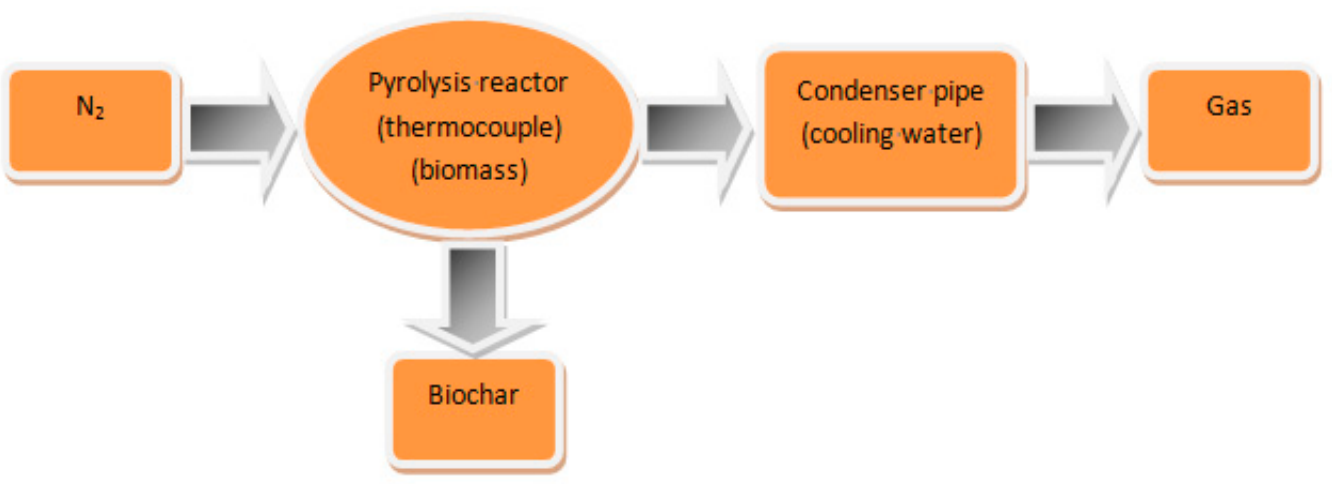

Figure 1. Schematic diagram of biochar production by pyrolysis.

(2) Gasification is a thermochemical reaction that converts a solid fuel into a gas composed primarily of hydrogen, carbon monoxide, carbon dioxide, methane, and nitrogen. The gasification process consists of four different steps, including drying, pyrolysis or dehydrogenation, combustion or oxidation, and gasification or reduction to thermolysis gas and biochar in the cooler and discharge port [51]. Compared to pyrolysis-based biochar, gasification-based biochar is different in its morphology and surface-function groups due to the use of oxidation to purify the gases [52].

(3) Hydrothermal carbonization is the process by which biomass material is carbonized via thermochemistry. This process involves a water environment at a temperature of $180-300{ }^{\circ} \mathrm{C}$ and a certain pressure $[53,54]$.

(4) Microwave pyrolysis is a process involving the rapid heating and extensive pyrolysis decomposition of biomass by inducing rapid dipole rotation and friction between biomass particles with microwave radiation in the range of $100-250{ }^{\circ} \mathrm{C}$ [55].

(5) Flash carbonization refers to the process of converting raw materials into solid and gas products by remaining at a pressure of $1-2 \mathrm{MPa}$ and a temperature of $300-600{ }^{\circ} \mathrm{C}$ for $30 \mathrm{~min}$. When baked under inert conditions [50], the raw materials are converted to hydrophobic solid products, while water and oxygen in the raw materials are removed. This process involves lighting a flash fire in a packed biomass bed under high pressure [56].

Hydrothermal carbonization and microwave pyrolysis are regarded as the optimal methods for preparing biochar because these methods are convenient, offer high yield, require only mild preparation conditions, produce no secondary pollution, and favor the retention of the surface-oxygen-containing functional groups. A summary of advantages and disadvantages for preparation methods of biochar is listed in Table 2. 
Table 2. Summary of advantages and disadvantages for preparation methods of biochar.

\begin{tabular}{ccc}
\hline Disadvantages & Advantages & The Preparation Methods \\
\hline Long response time & $\begin{array}{c}\text { Lower production cost, higher yields, and } \\
\text { low requirements for raw material size [49]. }\end{array}$ & Direct pyrolysis \\
\hline $\begin{array}{c}\text { The yield is lower than that of other } \\
\text { preparation methods [51]. }\end{array}$ & Fast reaction time [52]. & Gasification/ Flash carbonization \\
\hline $\begin{array}{c}\text { Prepared biochar has poor chemical } \\
\text { stability when applied under acidic, } \\
\text { alkaline, or high-temperature conditions } \\
{[57,58] .}\end{array}$ & $\begin{array}{c}\text { Does not require pre-drying, high carbon } \\
\text { content and abundant functional groups } \\
\text { can be obtained, and reduces energy } \\
\text { consumption [55]. }\end{array}$ & Hydrothermal carbonization \\
\hline Raw materials lack flexibility [59]. & $\begin{array}{c}\text { Uniform heating at the molecular level, } \\
\text { flexible, preparation process, portable } \\
\text { equipment, fast response, and energy } \\
\text { saving [60]. }\end{array}$ & Microwave pyrolysis \\
\hline
\end{tabular}

\subsubsection{Modified Biochar}

In some cases, the remediation of heavy-metal-contaminated soil by pure biochar yields unsatisfactory results. To improve the effect of biochar in the remediation of contaminated soil, the preparation method of modified biochar loaded with different elements has gradually become a research hotspot. At present, the main preparation methods for modified biochar are the impregnation method and the in situ synthesis method.

(1) Under the impregnation method, commercial or homemade biochar is loaded with the target elements by impregnating the biochar in a solution containing a modifier. Through this technology, various modified biochars can be prepared. Fe-Mn-Cemodified biochar derived from corn stalks is immersed in a mixed solution with $\mathrm{Fe}\left(\mathrm{NO}_{3}\right)_{3}, \mathrm{KMnO}_{4}$, and $\mathrm{Ce}_{2}\left(\mathrm{CO}_{3}\right)_{3}$ and carbonized at $300{ }^{\circ} \mathrm{C}$ for $0.5 \mathrm{~h}$. This process can not only change the form and distribution of As in soil but also create a suitable environment for microbial growth, thus influencing the geochemical cycle of As in soil [61].

(2) In Situ synthesis method: The target modification reagent is added directly into the raw material, followed by pyrolysis, chemical precipitation, and activation to obtain the modified biochar. In one report, the in situ synthesis method was conducted as follows: Pine shavings were immersed in $0.5 \mathrm{~mol} / \mathrm{L} \mathrm{Fe}\left(\mathrm{NO}_{3}\right)_{3}$ solution for $5.0 \mathrm{~h}$, dried in an oven at $105^{\circ} \mathrm{C}$, and then carbonized at $500{ }^{\circ} \mathrm{C}$ for $2.0 \mathrm{~h}$ in a nitrogen-protected muffle furnace to obtain an iron-bearing-modified biochar. This modified biochar was shown to offer good catalytic reduction performance for model dyes [62]. For example, Liu et al. [63] prepared Fe-rice-husk-derived biochar via the in situ synthesis method, which was used in the remediation of hexavalent-chromium-contaminated soil; the removal efficiency of hexavalent chromium using the Fe-rice-husk-derived biochar reached about $81 \%$. Khan et al. [64] used the in situ synthesis method to synthesize superparamagnetic nano- $\mathrm{Fe}_{3} \mathrm{O}_{4}$ biochar from Acacia mearnsii. The nano- $\mathrm{Fe}_{3} \mathrm{O}_{4}$ biochar offered excellent performance in soil remediation.

These two modification methods are easy to operate, their preparation cost is inexpensive [65], and the modifiers easily decompose in the carbonization process, thereby avoiding secondary contamination [66]. Thus, biochars modified by these two methods are widely used for reducing the bioavailability of heavy metals in soil. Compared with the impregnation method, the in situ synthesis method is more controllable, which enables the modified medium to stably attach onto the biochar matrix. Moreover, the adsorption capacity of modified biochar synthesized by the in situ synthesis method is higher than that under the impregnation method [50]. Therefore, the in situ synthesis method is the most effective technique between these two methods. 


\section{Remediation of Contaminated Soil by Biochar and Modified Biochar}

The remediation principles of contaminated soil include changing the forms of pollutants in soil and reducing the concentration of harmful substances. Actual soil remediation generally requires significant funding due to the complexity of soil pollution [67]. Due to its characteristics, biochar is considered to be a cost-effective soil-remediation material $[32,68]$ that can influence the physical and chemical properties of soil and increase the yield and quality of crops [44]. Modified biochar is considered to be a soil conditioner that can remediate heavy-metal-contaminated soil by improving the soil properties [52]. In this section, we summarize the different advantages of biochar and modified biochar in the remediation of contaminated soil, the factors affecting remediation, the remediation mechanisms, environmental monitoring, and the evaluation of environmental risk.

\subsection{The Different Advantages of Biochar and Modified Biochar for Remediation of Heavy-Metal-Contaminated Soil}

\subsubsection{The Different Advantage of Remediation Costs}

The applications of biochar and modified biochar in heavy-metal-contaminated-soil remediation have different advantages in economic effectiveness [69,70]. For example, sludge-based biochar can not only reduce the huge processing cost of urban sludge, but also recycle energy after further processing (such as sludge pyrolysis), which is in line with economic sustainable development [71,72]. Compared to original biochar, the production cost of modified biochar may be higher because of the use of some modified reagents. However, the actual application cost of modified biochars in soil remediation is lower, owing to many modified biochars having higher adsorption capacity and more times to reuse, thus further reducing the remediation costs. From the study of Irshad et al., goethite-modified biochar can be used to rehabilitate agricultural soils contaminated with cadmium and arsenic, and this method has the advantages of simple operation, high repair efficiency, good reproducibility, and cost saving [73]. Therefore, which biochar is selected for the remediation of heavy-metal-contaminated soil needs to be considered comprehensively [74].

\subsubsection{Remediation of Different Types of Contaminated Soil}

Biochars and modified biochars can remove various types and various concentrations of heavy metals (Table 3). In many cases, biochar is non-selective in the removal of heavy metals, so it is suitable for most types of contaminated soils. Biochar from distillers' grains could effectively promote the conversion of $\mathrm{Cr}, \mathrm{Ni}, \mathrm{Cu}, \mathrm{Pb}, \mathrm{Zn}$, and $\mathrm{Cd}$ to residue fractions in multi-contaminated paddy soil [75]. Koh et al. reported that, after arsenic- and heavymetals-contaminated acidic agricultural soil had added to it pristine buffalo weed biochar, the arsenic and heavy-metals concentrations in the soil solution and plants was relatively low in biochar-added experiments compared to the control treatment [76]. In order to increase the removal efficiency and to extend the application in special type of soil, some modified biochars are prepared. For example, applying Fe-modified biochar for in situ remediation of weakly alkaline $\mathrm{Cd}$-contaminated soils can alleviate the accumulation of $\mathrm{Cd}$ from soils to the maize plants [77]. The possible reason is that the addition of Fe-modified biochar increases the soil $\mathrm{pH}$ by $0.04-0.10$ units, which lead to cadmium ions forming carbonate binding species and manganese oxides binding species, and then reduces the mobility of cadmium. Compared to unmodified rice-straw biochar, the pyrolytic alkalimodified straw of biochar (KRBC) had the stronger ability to repair Zn-contaminated soil, because KRBC has higher aromatic properties, more $\pi$-conjugated aromatic structures, stronger cationic $\pi$ interactions, and more $\mathrm{Zn}$ forms stable structures under the action of $\mathrm{Zn}^{2+}-\pi$ [78]. In general, we can choose the original biochars to remediate heavy-metalcontaminated soil. For some special types of soil or pollutants, modifying biochars can be a good choice [79]. 
Table 3. Removing heavy metals by biochar or modified biochar.

\begin{tabular}{|c|c|c|c|c|}
\hline $\begin{array}{c}\text { Biomass and Its } \\
\text { Composite } \\
\text { Materials }\end{array}$ & $\begin{array}{c}\text { Pyrolysis } \\
\text { Temperature }\end{array}$ & Contaminants & Removal Rate & References \\
\hline \multirow[b]{2}{*}{ Wood } & $200^{\circ} \mathrm{C}$ & $\mathrm{Cd}$ & $93 \%$ & \multirow{2}{*}{ Debala et al. [34] } \\
\hline & $400^{\circ} \mathrm{C}$ & $\mathrm{Zn}$ & $90 \%$ & \\
\hline Pine bark & $420^{\circ} \mathrm{C}$ & $\mathrm{Cu}$ & $81 \%$ & Oustriere et al. [80] \\
\hline \multirow{4}{*}{ Wheat } & Not clear & $\mathrm{Zn}$ & $21.9 \%$ & \multirow{4}{*}{ Ail et al. [33] } \\
\hline & Not clear & $\mathrm{Pb}$ & $56.7 \%$ & \\
\hline & Not clear & $\mathrm{Cd}$ & $31.9 \%$ & \\
\hline & Not clear & $\mathrm{Cu}$ & $25.2 \%$ & \\
\hline $\begin{array}{l}\text { Fe-modified } \\
\text { rice straw }\end{array}$ & $300^{\circ} \mathrm{C}$ & As & $35.2 \%$ & Wu et al. [81] \\
\hline \multirow{3}{*}{$\begin{array}{l}\text { Hcl-modified } \\
\text { Coconut Shell }\end{array}$} & $800^{\circ} \mathrm{C}$ & $\mathrm{Cd}$ & $30.1 \%$ & \multirow{3}{*}{ Liu et al. [3] } \\
\hline & $800^{\circ} \mathrm{C}$ & $\mathrm{Zn}$ & $12.7 \%$ & \\
\hline & $800^{\circ} \mathrm{C}$ & $\mathrm{Ni}$ & $57.2 \%$ & \\
\hline
\end{tabular}

\subsubsection{Different Effects on Soil Nutrition and Physicochemical Property}

Biochar can improve the cycle of N, P, and K in soil, which can improve soil fertility and soil texture [82]. However, excessive use of biochar may increase or decrease soil alkalinity. Compared with original biochar, a multiple-modified biochar significantly increased soil dehydrogenase, organic matter content, and available potassium content. The enhancement of dehydrogenase and organic matter contents indicated that the surface catalytic activity of modified biochar was effectively enhanced. The pore size of modified biochar is larger than that of original biochar, which reduces the water permeability, strengthens the adsorption capacity of soil to easily leached potassium ions, and improves the content of available potassium. These increase the activities of microorganisms in soil, thus enhancing soil nutrients. In addition, soil fertility and root biomass of wheat seedlings were significantly increased as the modified biochar was applied [83].

Though adding biochar or modified biochar to soil can change the physical and chemical properties of soil, such as increasing soil $\mathrm{pH}$ value and cation-exchange capacity (CEC), and improving the total porosity of contaminated soil [84-86]. The excessive or inappropriate addition can cause soil some other problems such as acidification, nutritional imbalance, and secondary pollution [87]. Therefore, the appropriate addition ratio of biochar and modified biochar should be studied when using biochar or modified biochar to remediate heavy-metal-contaminated soil. It is very important to select suitable biochar feedstock according to the original physical and chemical properties and nutrients of heavy-metal-contaminated soil.

\subsubsection{Effect on Bioavailability of Heavy Metals in Soil}

Soil physical and chemical properties can significantly affect the stability of heavy metals in soil [88]. The addition of biochar and modified biochar to the soil leads to change the physicochemical property of the soil, thereby affecting the bioavailability of heavy metals in the soil [89]. For example, the addition of 5\% rice-straw biochar and 5\% alkalimodified rice-straw biochar could reduce the available $\mathrm{Zn}$ content in soil by $28.96 \%$ and $36.86 \%$, respectively [83]. It was positively correlated with the improvement of soil $\mathrm{pH}$ and soil organic carbon. The addition of sphagnum biochar significantly reduced the mobility of heavy metals and the bioavailability of $\mathrm{Pb}, \mathrm{Cu}$, and $\mathrm{Cd}$ in contaminated soil, also reduced by $97.8 \%, 100 \%$, and $77.2 \%$, respectively, through the coordination of metal electrons to $C$ [double bond, length as $\mathrm{m}$-dash] C ( $\pi$-electron) bonds [90]. In comparison to the application of pure biochar, $\mathrm{Cd}$ accumulation in brown rice decreased by $25.1 \%$ with sulfur-modified biochar amendment and by $34.6 \%$ with sulfur-iron-modified biochar addition, respectively, in the Cd-contaminated soil [91]. At the same time, the sulfur-iron-modified biochar 
amendment significantly decreased the Cd concentration in rice grains by $0.018 \mathrm{mg} / \mathrm{kg}$ in Cd-contaminated soil. In soil, because the addition of sulfur- and sulfur-iron-modified biochars decreased pore water $\mathrm{Cd}$ content by precipitation. David et al. reported that the available $\mathrm{Hg}$ concentration was lower in the soil treated by S-modified biochar than that in the soil treated by unmodified biochar, and the available $\mathrm{Hg}$ concentration in the soil was less than $200 \mu \mathrm{g} / \mathrm{L}$ with treated by 5\% S-modified biochar [92]. For arsenic-contaminatedsoil remediation, hexadecyl trimethyl ammonium bromide-modified maize straw biochar decreased the uptake of As by plants by $80.77 \%$ compared to the pristine maize straw biochar [93]. In general, biochars can influence the content distribution and species of heavy metals in soil by affecting the adsorption effect and solid-liquid ratio of soil, and then influence the bioavailability of heavy metals. In addition to the above reasons, for modified biochars, the soil $\mathrm{pH}$, organic carbon content, and REDOX property are also influenced, which further changes the bioavailability of heavy metals in soil.

\subsubsection{Effects on Yield and Quality of Crops after Remediation}

Pollution by heavy metals leads to the imbalance of soil crop nutrients, which may reduce the yield and quality of crops [94]. Application of biochars and modified biochars is a feasible technology to rapidly increase soil organic matter content and reduce the content of heavy-metal pollutants, and then achieve the purpose of increasing the yield and quality of crops.

Many studies have confirmed the beneficial effects of biochars and modified biochars on crops which are grown in heavy-metal-contaminated soil. Biochars derived from paper mill sludge showed a significantly high immobilization efficiency of $\mathrm{Cd}$ and $\mathrm{Pb}$ in soil, and the immobilization rates are $100 \%$ for $\mathrm{Cd}$ and $94 \%$ for $\mathrm{Pb}$. After biochars were added in soil, the dry weight of the lettuce was $26 \%$ higher than that of the control soil [95]. Further studies indicated that soil available Cd decreased by $56 \%$ after the application of $5.0 \%$ biochar amendment, and the weights of root, shoot, spike, and grain biomass were all increased compared to the control group [96]. Lian et al. also found that after adding Fe-Mn-Ce oxide-modified biochar in high-As-contaminated soil, the As concentrations in the roots, leaves, and grains of rice (Oryza sativa L.) were $69.36 \%, 47.27 \%$, and $73.58 \%$ lower, respectively, than that in the control group [97]. All these studies proved that biochar and modified biochar play an important role in increasing the yield and quality of crop [98].

The fundamental problem that leads to the low yield in soil is the deterioration of the physical properties of the soil. At present, the most ideal state is to use biochar and modified biochar to adjust the physical components of the soil, so as to optimize the soil proportion to achieve a "permanent" state of high fertility and avoid excessive dependence on chemical fertilizers.

\subsection{Factors Affecting the Remediation of Heavy-Metal-Contaminated Soil}

\subsubsection{Physical and Chemical Properties of Biochar and Modified Biochar}

Due to their excellent physical and chemical properties, biochar and modified biochar are used to alter the biological effectiveness of heavy metals in soil. Biochar is likely to be an alkaline substance when the raw materials mostly come from livestock or poultry dung. For example, due to its high ash content, the biochar prepared by chicken manure usually has a high $\mathrm{pH}$ value and its application can lead to soil becoming alkaline, resulting in the heavy metals (such as $\mathrm{Cu}^{2+}, \mathrm{Pb}^{2+}$, and $\mathrm{Zn}^{2+}$ ) in the soil forming hydroxide precipitates, thereby reducing the biochar's biological effectiveness [99]. The adsorption of heavy metals is also influenced by the components of biochar and modified biochar. For example, an increase in the proportion of zero-valent iron in biochar will increase the adsorption efficiency of $\mathrm{Cd}$ and As, thereby reducing the contents of Cd and As in soil [100].

\subsubsection{External Conditions}

Most studies suggest that the adsorption of heavy-metal ions by biochar and modified biochar is an endothermic process. The adsorption capacity of biochar increases with 
an increase in reaction temperature, which accelerates the adsorption of heavy metals. Therefore, ambient temperature is an important factor in the adsorption of biochar and modified biochar. Hoda et al. [101] studied the adsorption of $\mathrm{Cu}^{2+}, \mathrm{Pb}^{2+}$, and $\mathrm{Zn}^{2+}$ by biochar prepared with clay and chitosan composites, and the results showed that a high temperature was beneficial for metal-ion adsorption into the biochar, thus indicating that the adsorption process was endothermic. The effect of temperature on the adsorption of $\mathrm{Pb}^{2+}$ and $\mathrm{Cd}^{2+}$ by magnetic rubber-tree charcoal and magnetic rubber-bark charcoal was also examined by researchers. The removal efficiencies of $\mathrm{Pb}^{2+}$ and $\mathrm{Cd}^{2+}$ ions by the two charcoals both increased, with an increase in temperature from 25 to $45^{\circ} \mathrm{C}$ [102]. Thermodynamic analysis also showed that the adsorption was an endothermic reaction, which was consistent with the results of previous studies.

\subsubsection{Soil Types}

Soil type also influences the adsorption of heavy metals by biochar and modified biochar. Ahmad et al. [103] prepared three biochars from three different raw materialssoybean straw, peanut shells, and pine needles-which were used to adsorb heavy-metal ions in soil. The results showed that these biochars effectively reduced the mobility of $\mathrm{Pb}^{2+}$ and $\mathrm{Cu}^{2+}$ in shooting-range soil and also had a good adsorption effect for $\mathrm{Pb}^{2+}$ and $\mathrm{Zn}^{2+}$ in agricultural soil. A study by Chen et al. [104] showed that rice-hull biochar offered better performance in decreasing the availability of $\mathrm{Cu}^{2+}$ and $\mathrm{Cd}^{2+}$ in acidic soil. Hu et al. [105] also found that the effect of alkaline soil on heavy-metal removal was unsatisfactory compared with that of acidic soil. These studies indicate that biochar and modified biochar have different impact in the remediation of heavy metals in different soils.

Among these factors, the properties of biochar and modified biochar are the most important aspects that influence the remediation of heavy-metal-contaminated soil, followed by soil type. To improve the removal effect, researchers should first consider the properties of biochar and modified biochar to select the best options based on laboratory soil-culture experiments.

\subsection{Mechanism of Heavy-Metal-Contaminated Soil Remediation by Biochar and Modified Biochar}

In general, the mechanism removing heavy metals in soil mainly through adsorption, ion-exchange, electrostatic attraction, co-precipitation, and the complexing function of oxygen functional groups and $\pi$-electrons.

\subsubsection{Adsorption}

During the preparation processes of biochar and modified biochar, pore structures and large specific surface areas are generated. These factors allow the biochar to effectively adsorb heavy metals in soil. Besides, the adsorption property is further improved when the surface of biochar and modified biochar contain the alkaline minerals, negatively charged surface and functional groups. Some studies have shown that the surface adsorption of biochar is related to the presence of $\pi$ electrons [106,107]. Modifications can improve the surface properties of biochar and further enhance its ability to restore heavy-metalcontaminated soil [108].

\subsubsection{Complexation}

Biochar contains many hydroxyl, carboxyl, and other functional groups that are favorable for complexation with heavy-metal ions. The main mechanism is the complexation reaction by oxygen-containing functional groups and carboxyl groups of biochar. This putative complexation method is illustrated in Figure 2. Aromatic rings and hydroxyl groups on the surface of the biochar take part in the complexation reactions. 


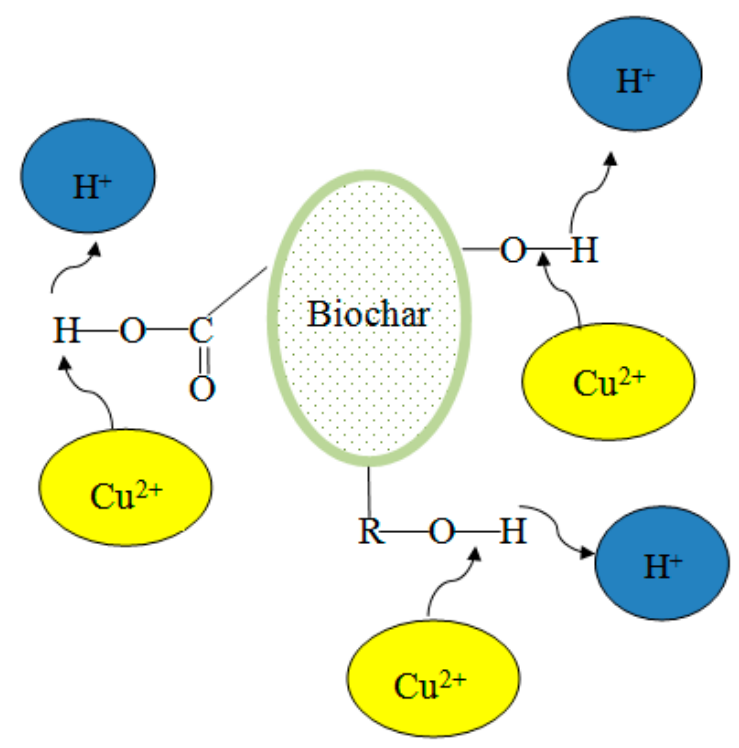

Figure 2. The proposed complexation method of biochar and copper ions.

\subsubsection{Precipitation}

The precipitation of heavy metals by biochar and modified biochar can occur by two pathways: (1) the addition of biochar and modified biochar increases the $\mathrm{pH}$ value of the original environment, which precipitates heavy-metal ions, and (2) inorganic components such as $\mathrm{PO}_{4}{ }^{3-}$ and $\mathrm{CO}_{3}{ }^{2-}$ in biochar and modified biochar can react with heavy-metal ions. Lead ion in soil is able to combine with the functional groups of $\mathrm{PO}_{4}{ }^{3-}, \mathrm{CO}_{3}{ }^{2-}$, hydroxyl, and carboxyl groups to form co-precipitates on the surface of sludge biochar. As the $\mathrm{pH}$ value was 5.0, $\mathrm{Pb}^{2+}$ mainly formed lead-phosphate deposits on the surface of the biochar (Figure 3):

$$
6 \mathrm{HPO}_{4}{ }^{2-}+9 \mathrm{~Pb}^{2+}+6 \mathrm{OH}^{-} \rightarrow \mathrm{Pb}_{9}\left(\mathrm{PO}_{4}\right)_{6}+6 \mathrm{H}_{2} \mathrm{O}
$$

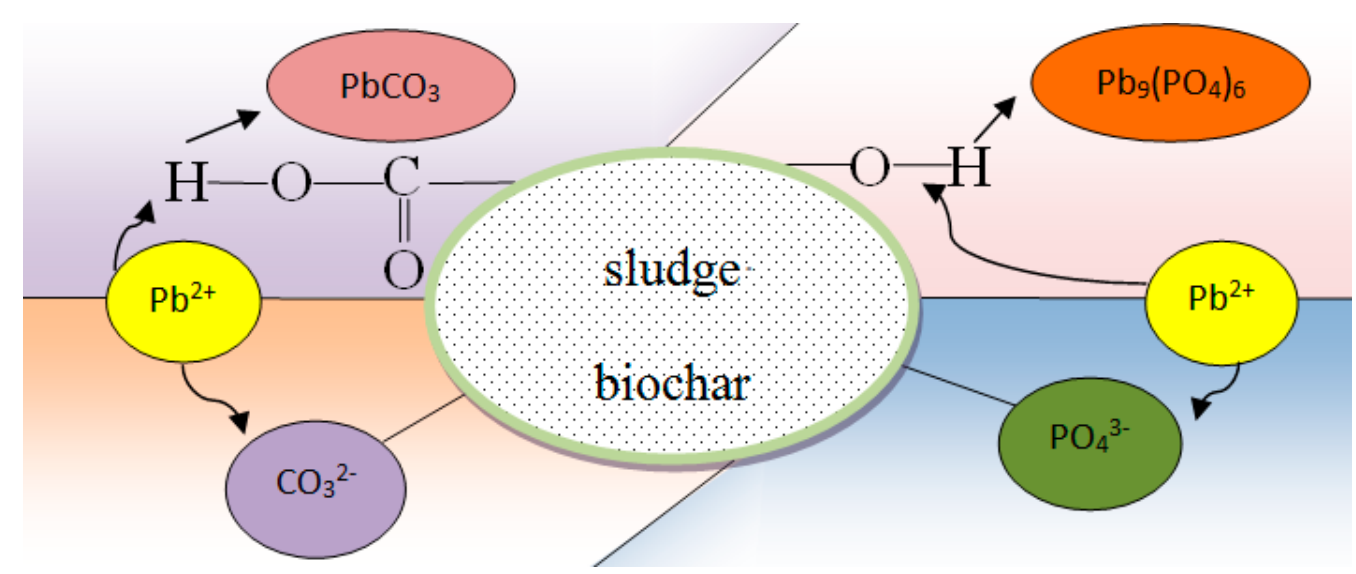

Figure 3. $\mathrm{Pb}^{2+}$ combines with functional groups to form co-precipitation on the surface of sludge biochar.

The co-precipitation mechanism of iron ions by biochar was as follows [64]:

$$
\begin{gathered}
\mathrm{Fe}^{3+}+3 \mathrm{OH}^{-} \rightarrow \mathrm{Fe}(\mathrm{OH})_{3}(\mathrm{~s}) \\
\mathrm{Fe}(\mathrm{OH})_{3}(\mathrm{~s}) \rightarrow \mathrm{FeO} \cdot \mathrm{OH}(\mathrm{s})+\mathrm{H}_{2} \mathrm{O} \\
\mathrm{Fe}^{2+}+2 \mathrm{OH}^{-} \rightarrow \mathrm{Fe}(\mathrm{OH})_{2}(\mathrm{~s}) \\
2 \mathrm{FeOOH}(\mathrm{s})+\mathrm{Fe}(\mathrm{OH})_{2}(\mathrm{~s}) \rightarrow \mathrm{Fe}_{3} \mathrm{O}_{4}(\mathrm{~s})+2 \mathrm{H}_{2} \mathrm{O}
\end{gathered}
$$




\subsubsection{Ion Exchange}

Ion exchange also plays a very important role in the removal of heavy metals from polluted soil by biochar and modified biochar. The high cation-exchange capacity on the surface of biochar and modified biochar can also improve the exchange of metal cations in soil. Rajapaksha et al. found that an ion-exchange reaction occurred between $\mathrm{Pb}^{2+}$ and $\mathrm{Ca}^{2+}$ in wastepaper biochar, which increased the adsorption efficiency of $\mathrm{Pb}$ (II) [109]. Generally speaking, the reaction formula of ion exchange can be expressed as:

$$
\mathrm{nC}-\mathrm{O}-\mathrm{X}+\mathrm{M}^{\mathrm{n}+}=\mathrm{nC}-\mathrm{O}-\mathrm{M}+\mathrm{nX}^{+}
$$

where $\mathrm{M}$ represents heavy metals, and $\mathrm{X}$ represents $\mathrm{Ca}^{2+}, \mathrm{Mg}^{2+}, \mathrm{K}^{+}$, or $\mathrm{Na}^{+}$in biochar, $\mathrm{n}$ represents the valence state.

\subsubsection{Electrostatic Attraction}

The essence of ion exchange is the electrostatic attraction between negatively charged groups on the surface of the biochar and positive charges $\left(\mathrm{Na}^{+}, \mathrm{Mg}^{2+}, \mathrm{K}^{+}, \mathrm{Ca}^{2+}\right.$, etc.) in the soil. The high cation-exchange capacity on the surface of biochar can also improve the exchange of metal cations in soil [110]. Electrostatic attraction between heavy-metal ions and biochar plays an important role in the immobilization process.

\subsubsection{Surface Redox}

Besides the effects of adsorption, ion-exchange, electrostatic attraction, precipitation, and the complexation, the heavy metals retained in the soil would undergo a series of processes such as plant uptake, leaching, and redox. In the treatment of heavy-metalcontaminated soil by biochar and modified biochar, surface redox also plays an important role, especially for heavy-metal ions in different valence states [64]. Biochar can act as an electron pump donating electrons to offer more oxidized species. Similar results were found by Vithanage et al. [111], who observed that As(III) was converted into low-toxic As(V) by iron oxide on the biochar surface. The results can be expressed as the following reactions:

$$
\begin{aligned}
& \text { Biochar } \equiv \mathrm{FeOH}_{(\mathrm{s})}+\mathrm{AsO}_{4}{ }^{3-}{ }_{(\mathrm{aq})}+3 \mathrm{H}^{+}{ }_{(\mathrm{aq})} \rightleftharpoons \mathrm{Bioch} a r \equiv \mathrm{FeH}_{2} \mathrm{AsO}_{4(\mathrm{~s})}+\mathrm{H}_{2} \mathrm{O}_{(\mathrm{l})} \\
& \text { Biochar } \equiv \mathrm{FeOH}_{(\mathrm{s})}+\mathrm{AsO}_{4}{ }^{3-}{ }_{(\mathrm{aq})}+2 \mathrm{H}^{+}{ }_{(\mathrm{aq})} \rightleftharpoons \text { Biochar } \equiv \mathrm{FeHAsO}_{4}{ }^{-}{ }_{(\mathrm{s})}+\mathrm{H}_{2} \mathrm{O}_{(\mathrm{l})} \\
& \text { Biochar } \equiv \mathrm{FeOH}_{(\mathrm{s})}+\mathrm{AsO}_{4}{ }^{3-}{ }_{(\mathrm{aq})}+\mathrm{H}^{+}{ }_{(\mathrm{aq})} \rightleftharpoons \text { Biochar } \equiv \mathrm{FeAsO}_{4}{ }^{2-}{ }_{(\mathrm{s})}+\mathrm{H}_{2} \mathrm{O}_{(\mathrm{l})}
\end{aligned}
$$

\subsubsection{Activating Microorganisms in Soil}

Microorganisms are an important component of the soil environment and also play an important role in remediation of soil pollution [112]. Some studies confirmed that biochar can enhance the activities of soil microorganisms, thereby improving their ability to degrade pollutants [113]. A study on the adsorption of $\mathrm{Cu}^{2+}$ in soil by modified chicken-manure biochar showed that the biochar played a positive role in the treatment of pollution because it improved the living environment of microorganisms and the soil bioavailability [114]. Some studies also found that biochar and modified biochar can increase the resilience of soil microorganisms [115] or the quantity of microorganisms, rather than change the soil's microbial community structure [116]. Notably, due to the toxicity of nanomaterials, the effect on microbial community composition in the soil should always be considered when using biochar loaded with nanomaterials [117].

To study the effects of adding biochar (or modified biochar) on the soil physical and chemical properties, microbial community and phytochemistry, and analyze the correlation among these factors, which can provide a theoretical basis for the application of biochar and modified biochar in the treatment of heavy-metal environmental pollution (Figure 4). 


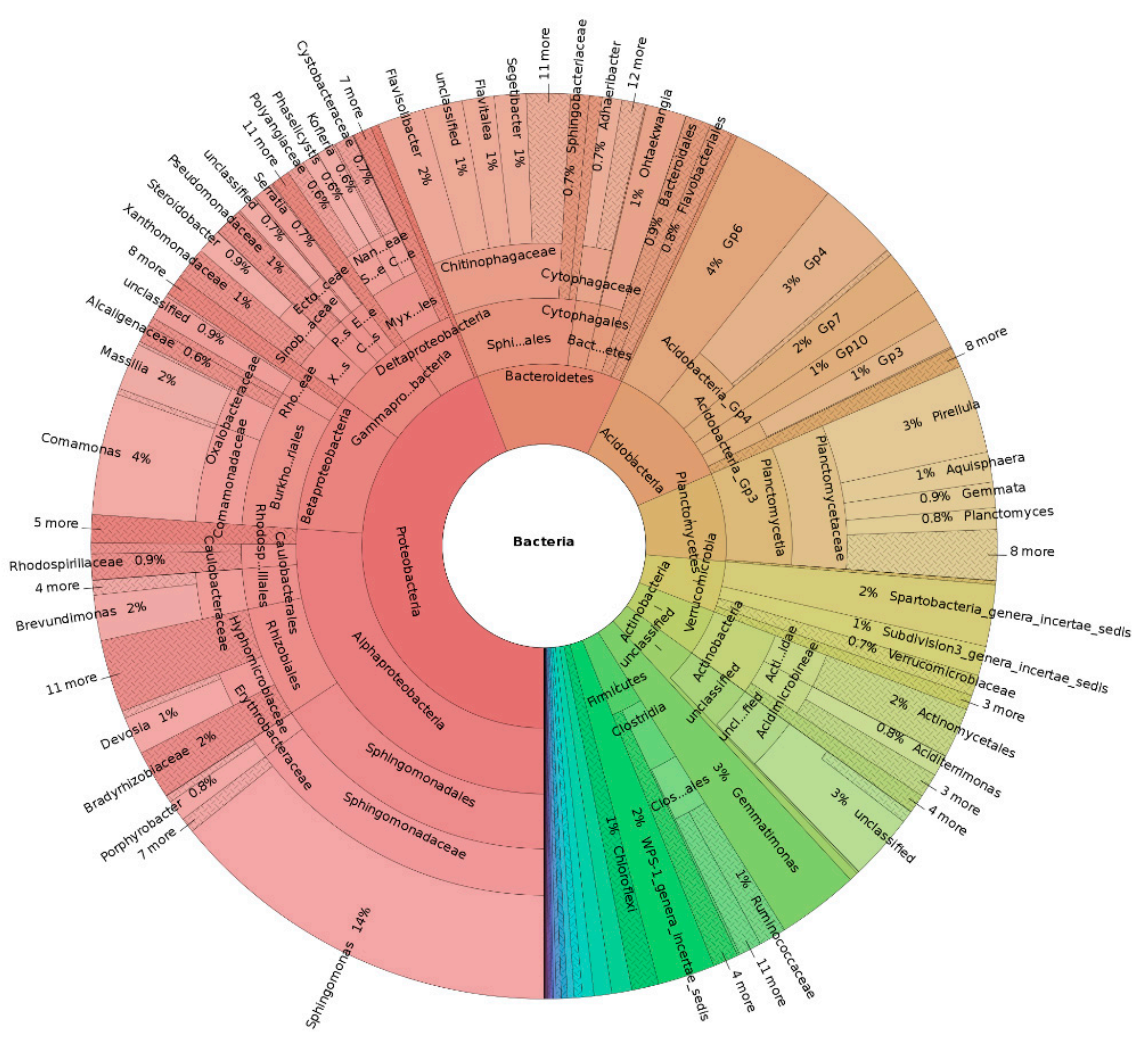

Figure 4. Multistage species composition diagram of single sample in arsenic-contaminated soil by magnetic iron oxide biochar.

\subsection{Environmental Monitoring and the Evaluation of Environmental Risk}

The physical and chemical properties of the soil change after adding biochar or modified biochar, including increases in the soil $\mathrm{pH}$ and total porosity, and improvements in the cation-exchange capacity (CEC) and water retention capacity, etc. [118]. These changes will affect the existence and migration of heavy metals in the soil and ultimately influence the remediation effects [119]. In order to assess the environmental risks of heavy metals after remediation, the soil should be monitored regularly. The monitored items include soil type, heavy-metal content, $\mathrm{pH}$, soil nutrient content, crop growth level, effects of biochar aging, complete destruction on heavy metals, etc. [120,121]. With the development of geographic information technology, today, remote sensing technology, global positioning technology, and photoelectric diffuse-reflection systems [122] provide advanced methods for monitoring soil after remediation using biochar or modified biochar. By using the data obtained from real-time monitoring with these technologies, the spatial variation distribution information of heavy metals in soil can be obtained [123], thus providing feedback on the remediation effects of biochar and modified biochar. Moreover, soil environmental monitoring can provide accurate data for soil-pollution investigations, prevention, and control, enabling researchers to scientifically and effectively carry out environmental soil remediation.

\section{Conclusions and Prospects}

Biochar and modified biochar are cheap, easy-to-obtain, offer good removal effects, and can be prepared using a variety of methods. Thus, we reviewed the recent progress in their applications in soil remediation, primarily providing an overview of the types and sources of raw materials, the preparation methods, and their effects on the resulting properties of biochar and modified biochar, as well as their differences and applications in the remediation of heavy-metal-contaminated soil. The mechanisms of heavy-metal removal were also illustrated, which include adsorption, complexation, precipitation, ion exchange, electrostatic attraction, surface oxidation, redox, and soil microbial activities. 
Thus, biochar and modified biochar are economical and effective materials for the remediation of heavy-metal-contaminated soil and are expected to be widely applied far into the future.

Considering the above advantages, the application of biochar and modified biochar in the remediation of contaminated soil is an important topic in current research. However, there are still several problems regarding their use in remediation, and their resolution represents future directions for research. (1) More experiments need to highlight the stability and toxicity of biochar and modified biochar through long-term investigations under different types of soils. (2) In the preparation and modification of biochar, environmentally friendly materials should be selected to avoid soil toxicity. (3) Beyond pyrolysis temperature, additive/modification methods, and soil types, there are numerous other factors affecting the functions of biochar and modified biochar that need to be explored. (4) Simple and fast follow-up environmental monitoring methods must be developed.

Author Contributions: Conceptualization, M.L. and H.H.; methodology, L.L.; resources, J.L.; data curation, Z.Z.; writing - original draft preparation, L.L. and J.L.; writing — review and editing, H.H. and Y.Z.; supervision, M.L.; project administration, H.H.; funding acquisition, M.L. All authors have read and agreed to the published version of the manuscript.

Funding: This research was supported by the National Natural Science Foundation of China (Grant No.: 52160017), Guangxi Natural Science Foundation Project (Grant No.: 2018GXNSFAA050044), Guangxi Science and Technology Planning Project (Grant No.: Guike-AD19110105, GuiKe-AD18126018), and the Research Startup Fund of Guilin University of Technology (Grant No.: GUTQDJJ2006022, GUTQDJJ2017072).

Institutional Review Board Statement: Not applicable.

Informed Consent Statement: Not applicable.

Data Availability Statement: Not applicable.

Acknowledgments: The authors would like to acknowledge the supported of Guilin University of Technology in providing a comfortable working environment.

Conflicts of Interest: The authors declare no conflict of interest.

\section{References}

1. Ling, Y.K.; Fye, L.B.; Loke, S.P.; Chyuan, O.H.; Chuan, L.T.; Hsin, C.W.; Poh, N.E.; Shu, C.J. Recent developments on algal biochar production and characterization. Bioresour. Technol. 2017, 246, 2-11.

2. Palaniyandi, S.A.; Yang, S.H.; Zhang, L.; Suh, J.-W. Effects of actinobacteria on plant disease suppression and growth promotion. Appl. Microbiol. Biotechnol. 2013, 97, 9621-9636. [CrossRef] [PubMed]

3. Liu, H.K.; Xu, F.; Xie, Y.L.; Wang, C.; Zhang, A.K.; Li, L.L.; Xu, H. Effect of modified coconut shell biochar on availability of heavy metals and biochemical characteristics of soil in multiple heavy metals contaminated soil. Sci. Total Environ. 2018, 645, 702-709. [CrossRef] [PubMed]

4. Basir-Cyio, M.; Napitupulu, M.; Inoue, T.; Anshary, A.; Rusydi, M.; Bakri, R. Pollution and contamination level of Cu, Cd, and Hg heavy metals in soil and food crop. Int. J. Environ. Sci. Technol. 2021, 6, 1-12. [CrossRef]

5. Wang, H.; Zhang, H.; Tang, H.Y.; Wen, J.W.; Li, A.N. Heavy metal pollution characteristics and health risk evaluation of soil around a tungsten-molybdenum mine in Luoyang, China. Environ. Earth Sci. 2021, 80, 293.

6. Kumar, A.; Amit, K.; Cabral-Pinto, M.M.S.; Chaturvedi, A.K.; Shabnam, A.A.; Subrahmanyam, G.; Mondal, R.; Gupta, D.K.; Malyan, S.K.; Kumar, S.S.; et al. Lead toxicity: Health hazards, influence on food chain, and sustainable remediation approaches. Int. J. Environ. Res. Publ. Health 2020, 17, 2179. [CrossRef] [PubMed]

7. Kumar, A.; Subrahmanyam, G.; Mondal, R.; Cabral-Pinto, M.M.S.; Shabnam, A.A.; Jigyasu, D.K.; Malyan, S.K.; Fagodiya, R.K.; Khan, S.A.; Kumar, A.; et al. Bio-remediation approaches for alleviation of cadmium contamination in natural resources. Chemosphere 2021, 268, 128855. [CrossRef]

8. Timofeev, I.; Kosheleva, N.; Kasimov, N. Contamination of soils by potentially toxic elements in the impact zone of tungstenmolybdenum ore mine in the Baikal region: A survey and risk assessment. Sci. Total Environ. 2018, 642, 63-76. [CrossRef]

9. Jiang, J.; Xu, R.K.; Jiang, T.Y.; Li, Z. Immobilization of $\mathrm{Cu}(\mathrm{II}), \mathrm{Pb}(\mathrm{II})$ and $\mathrm{Cd}(\mathrm{II})$ by the addition of rice straw derived biochar to a simulated polluted Ultisol. J. Hazard. Mater. 2012, 229-230, 145-150. [CrossRef]

10. Li, H.N.; Tian, Y.L.; Liu, W.; Long, Y.J.; Ye, J.; Li, B.X.; Li, N.; Yan, M.M.; Zhu, C.X. Impact of electrokinetic remediation of heavy metal contamination on antibiotic resistance in soil. Chem. Eng. J. 2020, 400, 125866. [CrossRef] 
11. Huang, S.H.; Rao, G.S.; Ashraf, U.; He, L.X.; Zhang, Z.Z.; Zhang, H.L.; Mo, Z.W.; Pan, S.G.; Tang, X.G. Application of inorganic passivators reduced $\mathrm{Cd}$ contents in brown rice in oilseed rape-rice rotation under $\mathrm{Cd}$ contaminated soil. Chemosphere 2020, 259, 127404. [CrossRef] [PubMed]

12. Massimo, F.; Donato, V.; Nunzio, F. Agronomic approaches for characterization, remediation, and monitoring of contaminated sites. Agronomy 2020, 10, 1335.

13. Liu, Z.C.; Chen, B.N.; Wang, L.A.; Urbanovich, O.; Nagorskaya, L.; Li, X.; Tang, L. A review on phytoremediation of mercury contaminated soils. J. Hazard. Mater. 2020, 400, 123138. [CrossRef]

14. Hong, Y.K.; Kim, J.W.; Lee, S.P.; Yang, J.E.; Kim, S.C. Heavy metal remediation in soil with chemical amendments and its impact on activity of antioxidant enzymes in Lettuce (Lactuca sativa) and soil enzymes. Appl. Biol. Chem. 2020, 63, 42. [CrossRef]

15. Li, H.S.; Jiang, L.; You, C.M.; Tan, B.; Yang, W.Q. Dynamics of heavy metal uptake and soil heavy metal stocks across a series of Masson pine plantations. J. Clean. Prod. 2020, 269, 122395. [CrossRef]

16. Xie, Y.L.; Luo, Y.; Sheng, M.P.; Peng, H.; Gu, Y.M.; Xu, H.; Zhao, Y. 24-Epibrassinolide combined with heavy metal resistant bacteria enhancing phytoextraction of Amaranthus hypochondriacus L. in Cd-contaminated soil. J. Hazard. Mater. 2020, $399,123031$. [CrossRef] [PubMed]

17. Gao, M.; Zeng, F.J.; Tang, F.; Wang, K.D.; Xu, X.Y.; Tian, G.M. An increasing Cr recovery from soil with catholyte-enhanced electrokinetic remediation: Effects on voltage redistribution throughout soil sections. Sep. Purif. Technol. 2020, $253,117553$. [CrossRef]

18. Figueroa, A.; Cameselle, C.; Gouveia, S.; Hansen, H.K. Electrokinetic treatment of an agricultural soil contaminated with heavy metals. J. Environ. Sci. Health A Tox. Hazard. Subst. Environ. Eng. 2016, 51, 691-700. [CrossRef]

19. Zhang, X.K.; Wang, H.L.; He, L.Z.; Lu, K.P.; Sarmah, A.; Li, J.W.; Bolan, N.S.; Pei, J.C.; Huang, H.G. Using biochar for remediation of soils contaminated with heavy metals and organic pollutants. Environ. Sci. Pollut. Res. 2013, 20, 8472-8483. [CrossRef]

20. Fan, Q.; Cui, L.; Quan, G.; Wang, S.; Sun, J.; Han, X.; Wang, J.; Yan, J. Effects of wet oxidation process on biochar surface in acid and alkaline soil environments. Materials 2018, 11, 2362. [CrossRef]

21. Cea, M.; Gonzalez, M.E.; Sangaletti, N.; Gonzalez, A.; Toro, C.; Navia, R. Biochar derived from agricultural and forestry wastes: Characterization and potential application for enzyme immobilization. New Biotechnol. 2012, 29, S60. [CrossRef]

22. Zambon, I.; Colosimo, F.; Monarca, D.; Cecchini, M.; Gallucci, F.; Proto, A.; Lord, R.; Colantoni, A. An innovative agro-forestry supply chain for residual biomass: Physicochemical characterisation of biochar from olive and hazelnut pellets. Energies 2016, 9 , 526. [CrossRef]

23. Bian, R.J.; Joseph, S.; Cui, L.Q.; Pan, G.X.; Li, L.Q.; Liu, X.Y.; Zhang, A.F.; Rutlidge, H.; Wong, S.W.; Chia, C.; et al. A three-year experiment confirms continuous immobilization of cadmium and lead in contaminated paddy field with biochar amendment. J. Hazard. Mater 2014, 272, 121-128. [CrossRef]

24. Zhu, L.; Lei, H.W.; Wang, L.; Yadavalli, G.; Zhang, X.S.; Wei, Y.; Liu, Y.P.; Yan, D.; Chen, S.L.; Ahring, B. Biochar of corn stover: Microwave-assisted pyrolysis condition induced changes in surface functional groups and characteristics. J. Anal. Appl. Pyrolysis 2015, 115, 149-156. [CrossRef]

25. Zhang, X.Y.; Gu, P.X.; Liu, X.Y.; Huang, X.; Wang, J.Y.; Zhang, S.Y.; Ji, J.H. Effect of crop straw biochars on the remediation of cd-contaminated farmland soil by hyperaccumulator Bidens pilosa L. Ecotoxicol. Environ. Saf. 2021, 219, 112332. [CrossRef] [PubMed]

26. Taghizadeh-Toosi, A.; Clough, T.J.; Condron, L.M.; Sherlock, R.R.; Anderson, C.R.; Craigie, R.A. Biochar incorporation into pasture soil suppresses in situ nitrous oxide emissions from ruminant urine patches. J. Environ. Qual. 2011, 40, 468-476. [CrossRef]

27. Hale, S.E.; Lehmann, J.; Rutherford, D.; Zimmerman, A.R.; Bachmann, R.T.; Shitumbanuma, V.; Toole, A.O.; Sundqvist, K.L.; Arp, H.P.H.; Cornelissen, G. Quantifying the total and bioavailable polycyclic aromatic hydrocarbons and dioxins in biochars. Environ. Sci. Technol. 2012, 46, 2830-2838. [CrossRef]

28. Yang, X.B.; Ying, G.G.; Peng, P.A.; Wang, L.; Zhao, J.L.; Zhang, L.J.; Yuan, P.; He, H.P. Influence of biochars on plant uptake and dissipation of two pesticides in an agricultural soil. J. Agric. Food Chem. 2010, 58, 7915-7921. [CrossRef]

29. Mierzwa, H.M.; Klimkowicz, P.A.; Gondek, K. Influence of Poultry Litter and Poultry Litter Biochar on Soil Microbial Respiration and Nitrifying Bacteria Activity. Waste Biomass Valorization 2018, 9, 379-389. [CrossRef]

30. Brockhoff, S.R.; Christians, N.E.; Killorn, R.J.; Horton, R.; Davis, D.D. Physical and mineral-nutrition properties of sand-based turfgrass root zones amended with biochar. Agron. J. 2010, 102, 1627-1631. [CrossRef]

31. Butphu, S.; Rasche, F.; Cadisch, G.; Kaewpradit, W. Eucalyptus biochar application enhances Ca uptake of upland rice, soil available $\mathrm{P}$, exchangeable $\mathrm{K}$, yield, and $\mathrm{N}$ use efficiency of sugarcane in a crop rotation system. J. Plant Nutr. Soil Sci. 2020, 183, 58-68. [CrossRef]

32. Lu, H.; Li, Z.; Fu, S.; Mendez, A.; Gasco, G.; Paz-Ferreiro, J. Effect of biochar in cadmium availability and soil biological activity in an anthrosol following acid rain deposition and aging. Water Air Soil Pollut. 2015, 226, 164. [CrossRef]

33. Ali, A.; Guo, D.; Jeyasundar, P.G.S.A.; Li, Y.; Xiao, R.; Du, J.; Li, R.G.; Zhang, Z.Q. Application of wood biochar in polluted soils stabilized the toxic metals and enhanced wheat (Triticum aestivum) growth and soil enzymatic activity. Ecotoxicol. Environ. Saf. 2019, 184, 109635. [CrossRef]

34. Debela, F.; Thring, R.W.; Arocena, J.M. Immobilization of heavy metals by co-pyrolysis of contaminated soil with woody biomass. Water Air Soil Pollut. 2011, 223, 1161-1170. [CrossRef] 
35. Lyu, H.H.; Zhang, Q.R.; Shen, B.X. Application of biochar and its composites in catalysis. Chemosphere 2020, $240,124842$. [CrossRef]

36. Guo, J.Y.; Gao, Q.F.; Jiang, S.L. Insight into dewatering behavior and heavy metals transformation during waste activated sludge treatment by thermally-activated sodium persulfate oxidation combined with a skeleton builder-wheat straw biochar. Chemosphere 2020, 252, 126542. [CrossRef]

37. Eduah, J.O.; Nartey, E.K.; Abekoe, M.K.; Breuning-Madsen, H.; Andersen, M.N. Phosphorus retention and availability in three contrasting soils amended with rice husk and corn cob biochar at varying pyrolysis temperatures. Geoderma 2019, 341, 10-17. [CrossRef]

38. Guo, J.Y.; Wen, X.Y.; Yang, J.W.; Fan, T. Removal of benzo(a)pyrene in polluted aqueous solution and soil using persulfate activated by corn straw biochar. J. Environ. Manag. 2020, 272, 111058. [CrossRef]

39. Cao, X.D.; Ma, L.N.; Liang, Y.; Gao, B.; Harris, W. Simultaneous immobilization of lead and atrazine in contaminated soils using dairy-manure biochar. Environ. Sci. Technol. 2011, 45, 4884-4889. [CrossRef]

40. Iriarte-Velasco, U.; Sierra, I.; Zudaire, L.; Ayastuy, J.L. Preparation of a porous biochar from the acid activation of pork bones Food Bioprod. Process. 2016, 98, 341-353. [CrossRef]

41. Karimi, M.; Tuesta, J.L.D.; Gonçalves, C.N.d.P.; Gomes, H.T.; Rodrigues, A.E.; Silva, J.A.C. Compost from municipal solid wastes as a source of biochar for $\mathrm{CO}_{2}$ capture. Chem. Eng. Technol. 2020, 43, 1336-1349. [CrossRef]

42. Wang, Q.H.; Lai, Z.Y.; Mu, J.; Chu, D.M.; Zang, X.R. Converting industrial waste cork to biochar as Cu (II) adsorbent via slow pyrolysis. Waste Manag. 2020, 105, 102-109. [CrossRef]

43. Cho, D.W.; Yoon, K.; Ahn, Y.; Sun, Y.Q.; Tsang, D.C.W.; Hou, D.Y.; Ok, Y.S.; Song, H. Fabrication and environmental applications of multifunctional mixed metal-biochar composites (MMBC) from red mud and lignin wastes. J. Hazard. Mater. 2019, 374, 412-419. [CrossRef]

44. Torri, C.; Samorì, C.; Adamiano, A.; Fabbri, D.; Faraloni, C.; Torzillo, G. Preliminary investigation on the production of fuels and bio-char from Chlamydomonas reinhardtii biomass residue after bio-hydrogen production. Bioresour. Technol. 2011, 102, 8707-8713. [CrossRef]

45. Kumar, A.; Pinto, M.C.; Candeias, C.; Dinis, P.A. Baseline maps of potentially toxic elements in the soils of Garhwal Himalayas, India: Assessment of their eco-environmental and human health risks. Land Degrad. Dev. 2021, 32, 3856-3869. [CrossRef]

46. Xiao, X.; Chen, B.; Chen, Z.M.; Zhu, L.Z.; Schnoor, J.L. Insight into multiple and multilevel structures of biochars and their potential environmental applications: A critical review. Environ. Sci. Technol. 2018, 52, 5027-5047. [CrossRef] [PubMed]

47. Kumar, A.; Jigyasu, D.K.; Kumar, A.; Subrahmanyam, G.; Mondal, R.; Shabnam, A.A.; Cabral-Pinto, M.M.S.; Malyan, S.K.; Chaturvedi, A.K.; Gupta, D.K.; et al. Nickel in terrestrial biota: Comprehensive review on contamination, toxicity, tolerance and its remediation approaches. Chemosphere 2021, 275, 129996. [CrossRef] [PubMed]

48. Ahmad, M.; Rajapaksha, A.U.; Lim, J.E.; Zhang, M.; Bolan, N.; Mohan, D.; Vithanage, M.; Lee, S.S.; Ok, Y.S. Biochar as a sorbent for contaminant management in soil and water: A review. Chemosphere 2014, 99, 19-33. [CrossRef] [PubMed]

49. Zhang, H.Y.; Yue, X.P.; Li, F.; Xiao, R.; Zhang, Y.P.; Gu, D.Q. Preparation of rice straw-derived biochar for efficient cadmium removal by modification of oxygen-containing functional groups. Sci. Total Environ. 2018, 631-632, 795-802. [CrossRef]

50. Zhou, Y.R.; Zhang, H.L.; Cai, L.; Guo, J.; Wang, Y.N.; Ji, L.L.; Song, W.D. Preparation and characterization of macroalgae biochar nanomaterials with highly efficient adsorption and photodegradation ability. Materials 2018, 11, 1709. [CrossRef]

51. Loha, C.; Gu, S.; Wilde, J.D.; Mahanta, P.; Chatterjee, P.K. Advances in mathematical modeling of fluidized bed gasification. Renew. Sustain. Energy Rev. 2014, 40, 688-715. [CrossRef]

52. Leng, L.J.; Yuan, X.Z.; Huang, H.J. Characterization and application of biochars from liquefaction of microalgae, lignocellulosic biomass and sewage sludge. Fuel Process. Technol. 2015, 129, 8-14. [CrossRef]

53. Yang, X.; Tsibart, A.; Nam, H.; Hur, J.; Ali, E.N.; Tack, F.M.G.; Wang, C.H.; Lee, Y.H.; Tsang, D.C.W.; Ok, Y.S. Effect of gasification biochar application on soil quality: Trace metal behavior, microbial community, and soil dissolved organic matter. J. Hazard. Mater. 2019, 365, 684-694. [CrossRef] [PubMed]

54. Funke, A.; Ziegler, F. Hydrothermal carbonization of biomass: A summary and discussion of chemical mechanisms for process engineering. Biofuels Bioprod. Biorefining 2010, 4, 160-177. [CrossRef]

55. Pauline, A.L.; Joseph, K. Hydrothermal carbonization of organic wastes to carbonaceous solid fuel-A review of mechanisms and process parameters. Fuel 2020, 279, 118472. [CrossRef]

56. Antal, M.M.K.; Paredes, L.S. Flash carbonization of biomass. Ind. Eng. Chem. Res. 2003, 42, 3690-3699. [CrossRef]

57. Álvarez, M.L.; Gascó, G.; Palacios, T.; Paz-Ferreiro, J.; Méndez, A. Feoxides-biochar composites produced by hydrothermal carbonization and pyrolysis of biomass waste. J. Anal. Appl. Pyrolysis 2020, 151, 104893. [CrossRef]

58. Baek, Y.S.; Lee, J.Y.; Park, S.K.; Bae, S.Y. The characteristics of the biochar with the synthetic food waste and wood waste for soil contaminated with heavy metals. J. Soil Sci. Groundw. Environ. 2014, 19, 1-7. [CrossRef]

59. Lin, Q.Y.; Zhang, J.; Yin, L.L.; Liu, H.; Zuo, W.; Tian, Y. Relationship between heavy metal consolidation and $\mathrm{H}_{2} \mathrm{~S}$ removal by biochar from microwave pyrolysis of municipal sludge: Effect and mechanism. Environ. Sci. Pollut. Res. 2021, 28, 27694-27702. [CrossRef]

60. Haeldermans, T.; Campion, L.; Kuppens, T.; Vanreppelen, K.; Cuypers, A.; Schreurs, S. A comparative techno-economic assessment of biochar production from different residue streams using conventional and microwave pyrolysis. Bioresour. Technol. 2020, 318, 124083. [CrossRef] 
61. Zhang, G.G.; Liu, X.W.; Gao, M.L.; Song, Z.G. Effect of Fe-Mn-Ce modified biochar composite on microbial diversity and properties of arsenic-contaminated paddy soils. Chemosphere 2020, 250, 126249. [CrossRef]

62. Li, H.; Jiang, D.N.; Huang, Z.Z.; He, K.; Zeng, G.M.; Chen, A.W.; Yuan, L.; Peng, M.; Huang, T.T.; Chen, G.Q. Preparation of silvernanoparticle-loaded magnetic biochar/poly(dopamine) composite as catalyst for reduction of organic dyes. J. Colloid Interface Sci. 2019, 555, 460-469. [CrossRef] [PubMed]

63. Liu, X.Y.; Yang, L.; Zhao, H.T.; Wang, W. Pyrolytic production of zerovalent iron nanoparticles supported on rice husk-derived biochar: Simple, in situ synthesis and use for remediation of $\mathrm{Cr}(\mathrm{VI})$-polluted soils. Sci. Total Environ. 2020, 708, 134479. [CrossRef]

64. Khan, M.Y.; Mangrich, A.S.; Schultz, J.; Grasel, F.S.; Mattoso, N.; Mosca, D.H. Green chemistry preparation of superparamagnetic nanoparticles containing $\mathrm{Fe}_{3} \mathrm{O}_{4}$ cores in biochar. J. Anal. Appl. Pyrolysis 2015, 116, 42-48. [CrossRef]

65. Souradeep, G.; Harn, W.K. Application of rice husk biochar as filler in cenosphere modified mortar: Preparation, characterization and performance under elevated temperature. Constr. Build. Mater. 2020, 253, 119083.

66. Su, M.H.; Azwar, E.; Yang, Y.F.; Sonne, C.; Yek, P.N.Y.; Liew, R.K.; Cheng, C.K.; Show, P.L.; Lam, S.S. Simultaneous removal of toxic ammonia and lettuce cultivation in aquaponic system using microwave pyrolysis biochar. J. Hazard. Mater. 2020, 396, 122610. [CrossRef]

67. Xu, W.Z.; Hou, S.Z.; Li, Y.Q.; Khan, M.A.; Luo, W.X.; Chen, Z.H.; Li, Y.Q.; Wu, X.D.; Ye, Z.Q.; Liu, D. Bioavailability and speciation of heavy metals in polluted soil as alleviated by different types of biochars. Bull. Environ. Contam. Toxicol. 2020, 104, 484-488. [CrossRef]

68. Eyvazi, B.; Jamshidi-Zanjani, A.; Darban, A.K. Immobilization of hexavalent chromium in contaminated soil using nano-magnetic $\mathrm{MnFe}_{2} \mathrm{O}_{4}$. J. Hazard. Mater. 2019, 365, 813-819. [CrossRef]

69. Zhao, B.W.; Xu, R.Z.; Ma, F.F.; Li, Y.W.; Wang, L. Effects of biochars derived from chicken manure and rape straw on speciation and phytoavailability of Cd to maize in artificially contaminated loess soil. J. Environ. Manag. 2016, 184, 569-574. [CrossRef]

70. Taraqqi-A-Kamal, A.; Atkinson, C.J.; Khan, A.; Zhang, K.K.; Sun, P.; Akther, S.; Zhang, Y.R. Biochar remediation of soil: Linking biochar production $\hat{A}$ with function in heavy metal contaminated soils. Plant Soil Environ. 2021, 67, 183-201. [CrossRef]

71. Wang, Z.P.; Shen, R.; Ji, S.B.; Xie, L.K.; Zhang, H.B. Effects of biochar derived from sewage sludge and sewage sludge/cotton stalks on the immobilization and phytoavailability of $\mathrm{Pb}, \mathrm{Cu}$, and $\mathrm{Zn}$ in sandy loam soil. J. Hazard. Mater. 2021, 419, 126468. [CrossRef] [PubMed]

72. Mandal, S.; Pu, S.Y.; Adhikari, S.; Ma, H.; Kim, D.H.; Bai, Y.C.; Hou, D.Y. Progress and future prospects in biochar composites: Application and reflection in the soil environment. Crit. Rev. Environ. Sci. Technol. 2021, 51, 219-271. [CrossRef]

73. Irshad, M.K.; Noman, A.; Alhaithloul, H.A.S.; Adeel, M.; Rui, Y.K.; Shah, T.; Zhu, S.H.; Shang, J.Y. Goethite-modified biochar ameliorates the growth of rice (Oryza sativa L.) plants by suppressing $\mathrm{Cd}$ and As-induced oxidative stress in Cd and As co-contaminated paddy soil. Sci. Total Environ. 2020, 717, 137086. [CrossRef]

74. Jiang, J.W.; Zhang, S.X.; Li, S.N.; Zeng, W.L.; Li, F.X.; Wang, W. Magnetized manganese-doped watermelon rind biochar as a novel low-cost catalyst for improving oxygen reduction reaction in microbial fuel cells. Sci. Total Environ. 2021, 802, 149989. [CrossRef]

75. Li, J.H.; Zhang, M.; Ye, Z.Y.; Yang, C.M. Effect of manganese oxide-modified biochar addition on methane production and heavy metal speciation during the anaerobic digestion of sewage sludge. J. Environ. Sci. 2019, 76, 267-277. [CrossRef] [PubMed]

76. Koh, I.H.; Kim, J.G.; Kim, G.S.; Park, M.S.; Kang, D.M.; Ji, W.H. Stabilization of Agricultural Soil Contaminated by Arsenic and Heavy Metals using Biochar derived from Buffalo Weed. J. Soil Sci. Groundw. Environ. 2016, 21, 87-100.

77. Sun, T.; Xu, Y.M.; Sun, Y.B.; Wang, L.; Liang, X.F.; Zheng, S.N. Cd immobilization and soil quality under Fe-modified biochar in weakly alkaline soil. Chemosphere 2021, 280, 130606. [CrossRef]

78. Liu, S.C.; Xie, Z.L.; Zhu, Y.T.; Zhu, Y.M.; Jiang, Y.; Wang, Y.J.; Gao, H.J. Adsorption characteristics of modified rice straw biochar for $\mathrm{Zn}$ and in-situ remediation of Zn contaminated soil. Environ. Technol. Innov. 2021, 22, 101388. [CrossRef]

79. Zhang, H.; Shao, J.G.; Zhang, S.H.; Zhang, X.; Chen, H.P. Effect of phosphorus-modified biochars on immobilization of Cu (II), Cd (II), and As (V) in paddy soil. J. Hazard. Mater. 2020, 390, 121349. [CrossRef]

80. Oustriere, N.; Marchand, L.; Galland, W.; Gabbon, L.; Lottier, N.; Motelica, M.; Mench, M. Influence of biochars, compost and iron grit, alone and in combination, on copper solubility and phytotoxicity in a $\mathrm{Cu}$-contaminated soil from a wood preservation site. Sci. Total Environ. 2016, 566-567, 816-825. [CrossRef]

81. Wu, C.; Cui, M.; Xue, S.; Li, W.; Huang, L.; Jiang, X.; Qian, Z. Remediation of arsenic-contaminated paddy soil by iron-modified biochar. Environ. Sci. Pollut. Res. 2018, 25, 20792-20801. [CrossRef]

82. Jindo, K.; Audette, Y.; Higashikawa, F.S.; Silva, C.A.; Akashi, K.; Mastrolonardo, G.; Sánchez-Monedero, M.A.; Mondini, C. Role of biochar in promoting circular economy in the agriculture sector. Part 1: A review of the biochar roles in soil N, P and K cycles. Chem. Biol. Technol. Agric. 2020, 7, 1137-1139. [CrossRef]

83. Wang, Y.Y.; Zheng, K.X.; Zhan, W.H.; Huang, L.Y.; Liu, Y.D.; Li, T.; Yang, Z.H.; Liao, Q.; Chen, R.H.; Zhang, C.S.; et al. Highly effective stabilization of $\mathrm{Cd}$ and $\mathrm{Cu}$ in two different soils and improvement of soil properties by multiple-modified biochar. Ecotoxicol. Environ. Saf. 2021, 207, 111294. [CrossRef]

84. Wang, Y.Y.; Ren, Q.; Li, T.; Zhan, W.H.; Zheng, K.X.; Liu, Y.D.; Chen, R.H. Influences of modified biochar on metal bioavailability, metal uptake by wheat seedlings (Triticum aestivum L.) and the soil bacterial community. Ecotoxicol. Environ. Saf. 2021, 220, 112370. [CrossRef] [PubMed]

85. Khorram, M.S.; Zhang, Q.; Lin, D.; Zheng, Y.; Fang, H.; Yu, Y. Biochar: A review of its impact on pesticide behavior in soil environments and its potential applications. J. Environ. Sci. 2016, 44, 269-279. [CrossRef] [PubMed] 
86. Wang, M.; Zhu, Y.; Cheng, L.; Andserson, B.; Hao, X.; Wang, D. Review on utilization of biochar for metal-contaminated soil and sediment remediation. J. Environ. Sci. 2018, 63, 156-173. [CrossRef]

87. Major, J.; Rondon, M.; Molina, D.; Riha, S.J.; Lehmann, J. Maize yield and nutrition during 4 years after biochar application to a Colombian savanna oxisol. Plant Soil 2010, 333, 117-128. [CrossRef]

88. Wang, Y.; Zhong, B.; Shafi, M.; Ma, J.W.; Guo, J.; Wu, J.S.; Ye, Z.Q.; Liu, D.; Jin, H.X. Effects of biochar on growth, and heavy metals accumulation of moso bamboo (Phyllostachy pubescens), soil physical properties, and heavy metals solubility in soil. Chemosphere 2019, 219, 510-516. [CrossRef] [PubMed]

89. Dixit, S.; Hering, J.G. Comparison of $\operatorname{arsenic}(\mathrm{V})$ and arsenic(III) sorption onto iron oxide minerals: Implications for arsenic mobility. Environ. Sci. Technol. 2003, 37, 4182-4189. [CrossRef]

90. Liang, B.; Lehmann, J.; Solomon, D.; Kinyangi, J.; Grossman, J.; O’Neill, B.; Skjemstad, J.O.; Thies, J.; Luizao, F.J.; Petersen, J.; et al. Black carbon increases cation exchange capacity in soils. Soil Sci. Soc. Am. J. 2006, 70, 1719-1730. [CrossRef]

91. Park, J.H.; Lee, S.J.; Lee, M.E.; Chung, J.W. Comparison of heavy metal immobilization in contaminated soils amended with peat moss and peatmoss-derived biochar. Environ. Sci. Processes Impacts 2016, 18, 514-520. [CrossRef]

92. Rajendran, M.; Shi, L.Z.; Wu, C.; Li, W.C.; An, W.H.; Liu, Z.Y.; Xue, S.G. Effect of sulfur and sulfur-iron modified biochar on cadmium availability and transfer in the soil-rice system. Chemosphere 2019, 222, 314-322. [CrossRef] [PubMed]

93. O'Connor, D.; Peng, T.Y.; Li, G.H.; Wang, S.X.; Duan, L.; Mulder, J.; Cornelissen, G.; Cheng, Z.L.; Yang, S.M.; Hou, D.Y. Sulfurmodified rice husk biochar: A green method for the remediation of mercury contaminated soil. Sci. Total Environ. 2018, 621, 819-826. [CrossRef]

94. Yan, C.Y.; Wen, J.; Wang, Q.; Xing, L.; Hu, X.H. Mobilization or immobilization? The effect of HDTMA-modified biochar on As mobility and bioavailability in soil. Ecotoxicol. Environ. Saf. 2021, 207, 111565. [CrossRef]

95. Kim, H.S.; Kim, K.R.; Ok, Y.S.; Lee, Y.K.; Kluge, B.; Wessolek, G.; Kim, W.I.; Kim, K. Examination of three different organic waste biochars as soil amendment for metal-contaminated agricultural soils. Water Air Soil Pollut. 2015, 226, 282. [CrossRef]

96. Abbas, T.; Rizwan, M.; Ali, S.; Zia-ur-Rehman, M.; Qayyum, M.F.; Abbas, F.; Hannan, F.; Rinklebe, J.; Ok, Y.S. Effect of biochar on cadmium bioavailability and uptake in wheat (Triticum aestivum L.) grown in a soil with aged contamination. Ecotox Environ Safe. 2017, 140, 37-47. [CrossRef]

97. Lian, F.; Liu, X.W.; Gao, M.L.; Li, H.Z.; Qiu, W.W.; Song, Z.G. Effects of Fe-Mn-Ce oxide-modified biochar on As accumulation, morphology, and quality of rice (Oryza sativa L.). Environ. Sci. Pollut. Res. 2020, 27, 18196-18207. [CrossRef] [PubMed]

98. Wen, E.; Yang, X.; Chen, H.; Shaheen, S.M.; Sarkar, B.; Xu, S.; Song, H.; Liang, Y.; Rinklebe, J.; Hou, D. Iron-modified biochar and water management regime-induced changes in plant growth, enzyme activities, and phytoavailability of arsenic, cadmium and lead in a paddy soil. J. Hazard. Mater. 2021, 407, 124344. [CrossRef]

99. Park, J.H.; Choppala, G.K.; Bolan, N.S.; Chung, J.W.; Chuasavathi, T. Biochar reduces the bioavailability and phytotoxicity of heavy metals. Plant Soil 2011, 348, 439-451. [CrossRef]

100. Qiao, J.T.; Liu, T.X.; Wang, X.Q.; Li, F.B.; Lv, Y.H.; Cui, J.H.; Zeng, X.D.; Yuan, Y.Z.; Liu, C.P. Simultaneous alleviation of cadmium and arsenic accumulation in rice by applying zero-valent iron and biochar to contaminated paddy soils. Chemosphere 2018, 195, 260-271. [CrossRef]

101. Hoda, A.; Ahmad, K.D.; Mahmoud, A.; Raymond, Y.; Bita, A.; Abbas, Z.; Sjoerd, E.A.T.M. Utilization of a novel chitosan/clay/biochar nanobiocomposite for immobilization of heavy metals in acid soil environment. J. Polym. Environ. 2017, 26, 2107-2119.

102. Dinesh, M.; Kumar, H.; Sarswat, A.; Alexandre, F.M.; Pittman, C.U. Cadmium and lead remediation using magnetic oak wood and oak bark fast pyrolysis biochars. Chem. Eng. J. 2014, 236, 513-528.

103. Ahmad, M.; Lee, S.S.; Lee, S.E.; Wabel, M.I.A.; Tsang, D.C.W.; Ok, Y.S. Biochar-induced changes in soil properties affected immobilization/mobilization of metals/metalloids in contaminated soils. J. Soils Sediments 2016, 17, 717-730. [CrossRef]

104. Chen, L.; Guo, L.; Zhou, Q.C.; Liu, M.J.; Zhan, S.W.; Pan, X.H.; Zeng, Y.J. Response of soil fertility and Cu and Cd availability to biochar application on paddy soils with different acidification levels. Biomass Convers. Biorefin. 2020, 1, 1-10. [CrossRef]

105. Hu, Y.M.; Zhang, P.; Yang, M.; Liu, Y.Q.; Zhang, X.; Feng, S.S.; Guo, D.W.; Dang, X.L. Biochar is an effective amendment to remediate Cd-contaminated soils-a meta-analysis. J. Soils Sediments 2020, 20, 3884-3895. [CrossRef]

106. Zhang, M.; Gao, B.; Yao, Y.; Xue, Y.W.; Inyang, M.D. Synthesis, characterization, and environmental implications of graphenecoated biochar. Sci. Total Environ. 2012, 435-436, 567-572. [CrossRef]

107. Xiong, X.N.; Yu, I.K.M.; Cao, L.C.; Tsang, D.C.W.; Zhang, S.C.; Ok, Y.S. A review of biochar-based catalysts for chemical synthesis, biofuel production, and pollution control. Bioresour. Technol. 2017, 246, 254-270. [CrossRef]

108. Wang, J.L.; Wang, S.Z. Preparation, modification and environmental application of biochar: A review. J. Cleaner Prod. 2019, 227, 1002-1022. [CrossRef]

109. Rajapaksha, A.U.; Ahmad, M.; Vithanage, M.; Kim, K.R.; Chang, J.Y.; Lee, S.S.; Ok, Y.S. The role of biochar, natural iron oxides, and nanomaterials as soil amendments for immobilizing metals in shooting range soil. Environ. Geochem. Health 2015, 37, 931-942. [CrossRef]

110. Dai, Z.; Meng, J.; Shi, Q.; Xu, B.; Lian, Z.; Brookes, P.C.; Xu, J.M. Effects of manure- and lignocellulose-derived biochars on adsorption and desorption of zinc by acidic types of soil with different properties. Eur. J. Soil Sci. 2016, 67, 40-50. [CrossRef]

111. Vithanage, M.; Herath, I.; Joseph, S.; Bundschuh, J.; Bolan, N.; Ok, Y.S.; Kirkham, M.B.; Rinklebe, J. Interaction of arsenic with biochar in soil and water: A critical review. Carbon 2017, 113, 219-230. [CrossRef] 
112. Guo, D.C.; Fan, Z.Z.; Lu, S.Y.; Ma, Y.J.; Nie, X.H.; Tong, F.P.; Peng, X.W. Changes in rhizosphere bacterial communities during remediation of heavy metal-accumulating plants around the Xikuangshan mine in southern China. Sci. Rep. 2019, 9, 1947. [CrossRef] [PubMed]

113. Li, X.N.; Yao, S.; Bian, Y.R.; Jiang, X.; Song, Y. The combination of biochar and plant roots improves soil bacterial adaptation to PAH stress: Insights from soil enzymes, microbiome, and metabolome. J. Hazard. Mater. 2020, 400, 123227. [CrossRef]

114. Meier, S.; Curaqueo, G.; Khan, N.; Bolan, N.; Rilling, J.; Vidal, C.; Fernández, N.; Acuña, J.; González, M.E.; Cornejo, P.; et al. Effects of biochar on copper immobilization and soil microbial communities in a metal-contaminated soil. J. Soils Sediments 2015, 17, 1237-1250. [CrossRef]

115. Shen, G.Q.; Ashworth, D.J.; Gan, J.J.; Yates, S.R. Biochar amendment to the soil surface reduces fumigant emissions and enhances soil microorganism recovery. Environ. Sci. Technol. 2016, 50, 1182-1189. [CrossRef] [PubMed]

116. Yu, L.; Yu, M.J.; Lu, X.; Tang, C.X.; Liu, X.M.; Brookes, P.C.; Xu, J.M. Combined application of biochar and nitrogen fertilizer benefits nitrogen retention in the rhizosphere of soybean by increasing microbial biomass but not altering microbial community structure. Sci. Total Environ. 2018, 640-641, 1221-1230. [CrossRef] [PubMed]

117. Du, W.C.; Sun, Y.Y.; Ji, R.; Zhu, J.G.; Wu, J.C.; Guo, H.Y. $\mathrm{TiO}_{2}$ and $\mathrm{ZnO}$ nanoparticles negatively affect wheat growth and soil enzyme activities in agricultural soil. J. Environ. Monit. 2011, 13, 822-828. [CrossRef]

118. Chen, D.; Guo, H.; Li, R. Low uptake affinity cultivars with biochar to tackle Cd-tainted rice: A field study over four rice seasons in Hunan, China. Sci. Total Environ. 2016, 541, 1489-1498. [CrossRef]

119. Zhang, X.Y.; Su, C.; Liu, X.Y.; Liu, Z.G.; Gu, P.X.; Deng, M.; Liu, Q. Periodical changes of dissolved organic matter (DOM) properties induced by biochar application and its impact on downward migration of heavy metals under flood conditions. J. Cleaner Prod. 2020, 275, 123787. [CrossRef]

120. Murtaza, G.; Ahmed, Z.; Usman, M.; Tariq, W.; Ullah, Z.; Shareef, M.; Iqbal, H.; Waqas, M.; Tariq, A.; Wu, Y.F.; et al. Biochar induced modifications in soil properties and its impacts on crop growth and production. J. Plant Nutr. 2021, 44, 1677-1691. [CrossRef]

121. Bovsun, M.A.; Castaldi, S.; Nesterova, O.V.; Semal, V.A.; Sakara, N.A.; Brikmans, A.V.; Khokhlova, A.I.; Karpenko, T.Y. Effect of Biochar on Soil $\mathrm{CO}_{2}$ Fluxes from Agricultural Field Experiments in Russian Far East. Agronomy 2021, 11, 1559. [CrossRef]

122. Chen, Z.X.X.; Yang, J.K.; Yang, X.T.; Zhao, Y.M.; Kang, J.Q.; Yang, F.Y.; Zhang, Y.F.; Cheng, M.; Wang, G.Z.; Duanmu, Q.D. Porous $\mathrm{Si} / \mathrm{TiO}_{2}$ nanowire photoanode for photoelectric catalysis under simulated solar light irradiation. Appl. Organomet. Chem. 2018, 32, 4356. [CrossRef]

123. Liu, W.J.; Chai, G.L.; Deng, W.B. A combination of finite mixture distribution model with geo-statistical models to study spatial patterns and hazardous areas of heavy metals in cropland soils of the Guanzhong Plain, Northwest China. Chemosphere 2021, 283, 131222. [CrossRef] [PubMed] 